\title{
External Environmental Analysis in Strategic Planning for The Development of The Quality of Educational Resources in Madrasah Aliyah Bandar Lampung City
}

\author{
Mahmudin Aris Rayusman ${ }^{1}$, Siti Patimah ${ }^{2}$, Agus Pahrudin ${ }^{3}$, Andi Thahir ${ }^{4}$ \\ \{arisrayusman@yahoo.co.id ${ }^{1}$, sitipatimah@radenintan.ac.id ${ }^{2}$, agus.pahrudin@ radenintan.ac.id ${ }^{3}$, \\ andithahir@radenintan.ac.id $\left.{ }^{4}\right\}$
}

Postgraduate student of the Islamic Education Management Study Program, UIN Raden Intan Lampung ${ }^{1}$, Senior Lecturer in Islamic Education Management Postgraduate Program at UIN Raden Intan Lampung ${ }^{2}$, Senior Lecturer in Islamic Education Management Postgraduate Program at UIN Raden Intan Lampung ${ }^{3}$, Senior Lecturer in Islamic Education Management Postgraduate Program at UIN Raden Intan Lampung ${ }^{4}$

\begin{abstract}
Increasing the resources of teachers is very important because teachers are the engine of education. Efforts to increase teacher resources require a well-planned and well-planned strategic plan in order to achieve optimal goals. In order for planning to increase teacher resources to be effective and efficient, it requires an analysis of the external environment. Through this analysis of the external environment, opportunities and threats will be identified as a basis for preparing plans to increase teacher resources. This study uses a qualitative approach which aims to analyze the external environment in formulating a strategic plan for improving the quality of educational resources at Madrasah Aliyah in Bandar Lampung. The results of this study revealed that there was a clear legal basis; technological support; Economic situation; organization of teachers; colleges of teachers; government support. By analyzing the external environment, there are opportunities and threats seen from the support aspect, the employee aspect and the competitor aspect. The recommendations made are necessary and important for carrying out an analysis of the external environment in order to increase the resources of teachers in a more effective and efficient manner.
\end{abstract}

Keywords: external environment, strategic planning, educational resources

\section{Introduction}

The problem of the quality of education is a central issue in the world of national education, in particular in relation to the low quality of education at each level and educational unit. Although the government has strived to improve the quality of education through training and upgrading the skills of teachers, purchasing textbooks, improving educational facilities and infrastructure, it cannot be denied that the quality education in Indonesia remains alarming. Based on data from UNESCO in the Global Education Monitoring (GEM) 2016, education in Indonesia is ranked 10th out of 14 developing countries. The problem of the quality of education is a central issue in the world of national education, in particular in relation to the low quality of education at each level and educational unit. Although the government has strived to improve the quality of education through training and upgrading the skills of teachers, purchasing textbooks, improving educational facilities and infrastructure, it cannot be denied that the quality education in Indonesia remains alarming.

The quality of education in Indonesia, according to data from UNESCO in the Global Education Monitoring (GEM) 2016, is ranked 10th out of 14 developing countries. Based on the PISA (Program for International Student Assessment) report, Indonesia's education rankings in the world are ranked 62 in the world in science, 63 in mathematics, and 64 in reading. Still under Singapore, Vietnam and Thailand. PISA itself is a survey that tests the abilities of 15-year-olds in three areas, namely reading, math and science. This survey was 
launched by the Organization for Economic Co-operation and Development (OECD). Based on this data, he confirms that the quality of education in Indonesia is still low and needs the efforts of various parties to improve it again.

One of the factors that determines the quality of education is the quality of its educational resources. Based on the data obtained, the quality of educators in Indonesia ranks 14th out of 14 developing countries in the world. Meanwhile, the number of teachers has increased by $382 \%$ since $1999 / 2000$ to reach over 3 million, and among them there are still $25 \%$ of teachers who did not meet the academic qualification requirements and $52 \%$ do not have a professional certificate. In contrast, the competence of educators in a country with the fourth largest population in the world is classified as very low. Data from the Ministry of Education and Culture shows that among the 1.6 million participants in the Teacher Proficiency Test, more than 1.3 million of them have scores below 60 , worth between 0 and 100. Also on this test, only 192 teachers obtained scores above 90 . While nearly 130,000 of them only obtained a score below 30. The low capacity of this teaching body was an impact on the quality of education in all regions. In contrast, the competence of educators in the country with the fourth largest population in the world is considered very low. Data from the Ministry of Education and Culture shows that among the 1.6 million participants in the Teacher Proficiency Test, more than 1.3 million of them have scores below 60, ranging from 0 to 100 . Also on this test, only 192 teachers obtained scores above 90 . While nearly 130,000 of them could only obtain a score below 30 . The low capacity of this teaching body has an impact on the quality of education in each region.

Based on the data obtained regarding the quality of education in the province of Lampung, in particular in the city of Bandar Lampung in the educational institutions of Madrasah Aliyah, it appears from the accreditation value obtained that only $12,5 \%$ is accredited A. Even $44 \%$ is still accredited C. Data shows that the quality of education of Madrasah Aliyah in the city of Bandar Lampung still needs to be improved. The results of the 2019 Teacher Proficiency Test in Lampung Province, the average scores of the Teacher Proficiency Test for teachers was 49.44. Meanwhile, the average score on the professional proficiency test was 55.07, with an average score on the overall teacher proficiency test of 53.38. Meanwhile, for teachers in Bandar Lampung, the average score on the Teaching Proficiency Test was 52.82. The mean Professional Proficiency Test score for teachers in Bandar Lampung was 58.73, with the mean Global Proficiency Test score 56.96. These data show that the competence of educators in Lampung Province and Bandar Lampung City is still very low.

The development of human resources in Indonesia must be a top priority for the education sector in Indonesia. This is because the weakness of human resources resulting from education has resulted in the weakness of Indonesia due to the recession in other sectors like the economic sector. As Lynda Gratton stated, that human resources are seen to have a greater role in the success of an organization, so many organizations today realize that the human element in organizations provides a competitive advantage[1]. Even the research results of Kadek Hengki Primayana show that by improving quality, human resources become influential because human resources, in this case teachers, are a central factor in education which is very important to improve the quality of education [2].

In educational institutions, educational resources are at the forefront of the institution's educational process. The educational process will not be successful without the role of the teacher. These educational resources will have great potential to advance education, if they are professional in managing their learning. It can therefore be said that teachers' resources can be one of the factors holding back the improvement of the quality of education.

Developing good quality teaching resources is not easy, it requires a mature, structured and planned strategic plan, so that teacher resource development efforts can achieve the objectives optimally, effectively and efficiently. According to Nasir Usman, in the process of human resource development, the first thing to do is to design a teacher development plan based on the results of the analysis and assessment of organizational and individual needs [3]. 
Activities carried out at this stage of strategic planning include carrying out an external environment scan [4].

The external environment should be analyzed to determine the opportunities and threats the organization will face. The external environment as the main obstacle to the main actions of a manager, the analysis of the environment is an important step in the strategic process. Because the environment of an organization, in large part, limits the options available to management. A strategy that works is a strategy suited to the environment. The research results of Muscalu, et al., Who state that the external environment causes changes in the Overall activities of the organization, the consequence is to increase the efficiency and competitiveness of the organization [5]. Riston suggests that the benefits of external analysis include (1) raising management awareness of environmental changes (2) improving resource allocation decisions (3) facilitating risk management [6].

Based on these results, in order to increase organizational efficiency and competitiveness, decisions made by managers must take into account the links between the organization and the external environment. One of the most important characteristics of an organization is its ability to adapt to changes that occur outside the organization. This dependence can be evidenced by the most important external factors affecting the activities of the organization.

\section{Literature Review}

\subsection{External Environment in Strategic Planning}

The external environment are factors that come from outside the organization and which usually arise independently of the operational situation facing the organization concerned, but which have an impact on the management and operational processes within the organization. the organization [7]. Another view was expressed by Akdon that the external environment is made up of opportunities and challenges that exist outside of the organization and that management cannot handle [8]. Thus, the external environment is a factor external to the organizational environment that can offer opportunities or threats to the organization.

Thomas L. Wheelen and J. David Hunger, the external environment is divided into two, namely the social environment (social environment) and the work environment (work environment). The social environment, including: (1) economic power (2) technological power (3) the power of political law (4) socio-cultural power. Work environment, made up of government, local communities, suppliers, competitors, customers, creditors, unions, special interest groups and professional associations [9]. The most important external factors affecting the activities of the organization are demographic, economic and technical characteristics. and technological, socio-cultural, political, legislative, natural and international environment [5].

In general, the external environmental analysis will cover both the macro environment and the industrial environmental aspects. The macro-environment includes aspects related to political, legal, economic, social and technological aspects that can affect organizational activities. Meanwhile, the industrial environment is an environment closer to the business activities of the organization [10]. Julieta Ojeda Gomez's external environment consists of a macro-environment and a micro-environment. The macro-environment includes sociocultural, political, technological, demographic and economic aspects. At the same time, the actors of the micro-environment are directly involved in the company and also affect the company, made up of suppliers, customers, intermediary agents, government agencies and competitors [11].

The most important external factors affecting the working environment of an organization are the factors that determine the environment: demographic, economic, technical and technological, socio-cultural, political, legal, natural and international. Organizations can function effectively if they are aware of external environmental factors as well as ongoing changes, continually adapting to the demands of the external environment. In this regard, it 
should be emphasized that there is an interaction between an organization and its external environment, both near and far.

Based on this explanation, when formulating a strategic plan, the organization must take into account the opportunities and threats of the external environment, present and future. Consequently, the organization must be attentive to any stimulus from the external environment, must constantly adapt to it and above all involve the adaptation of knowledge and information. Based on this explanation, when formulating a strategic plan, the organization must take into account the opportunities and threats of the external environment, present and future. Consequently, the organization must be attentive to any stimulus from the external environment, must constantly adapt to it and above all involve the adaptation of knowledge and information.

\section{Methods}

This type of research is a descriptive study using a qualitative approach. This research was conducted at Madrasah Aliyah in the city of Bandarlampung, Province of Lampung, i.e. 16 Madrasah Aliyah with details on 2 (two) Madrasah Aliyah with state status and 14 Madrasah Aliyah with private status. The data sources for this qualitative study were chosen on purpose and were a snowball sampling, including the head of the madrasah and his representatives, as well as the teachers of Madrasah Aliyah in Bandarlampung. The data collection tools for this study were interviews, observation and documentation. The data analysis technique used in qualitative research is inductive, that is, an analysis based on the obtained data, then a specific relationship model is developed. In this study, to obtain the validity of the data, triangulation was used.

\section{Result and Discussion}

The results of the data collection can be identified from the external environment of Madrasah Aliyah in the city of Bandar Lampung from a legal perspective, the efforts to develop the educational resources of Madrasah Aliyah in the city of Bandar Lampung have a solid legal basis, including Law number 20 of 2003 concerning the national education system, in particular Chapter XI. Concerning Educators and Education Personnel, Government Regulation No. 19 of 2005 Regarding National Education Standards, Regulation of the Minister of National Education of the Republic of Indonesia No. 16 of 2007 Regarding Qualification Academic and Teacher Competence Standards and Law No. 14 of 2005 on Teachers and Lecturers.

Another result of identifying the external environment in the development of educational resources of Madrasah Aliyah in Bandarlampung City, there are several teaching colleges in Bandarlampung which can help Madrasah Aliyah in Bandarlampung to prepare a large number of professional educators. , so that they can become a force for the Madrasahs. Aliyah in the city of Bandar Lampung in developing a strategic plan to improve the quality of educational resources.

The external environment has identified several teacher organizations that are still striving to develop the quality of educational resources in Lampung province in general and in Bandar Lampung city in particular, such as the Subject Teachers' Conference (MGMP), Similar Competencies (APKS) PGRI Lampung Province, Lampung Province Nahdhatul Ulama Teachers Association, Lampung Province Muhammadiyah Teachers Forum, Indonesian Association of Education Researchers, Indonesian Association of Madrasah Teachers and Indonesian Association educational assessment.

The power of technology in the city of Bandar Lampung is another external environment to be considered when developing a strategic plan to improve the quality of educational resources for Madrasah Aliyah teachers in Bandar Lampung. According to observations, the technological facilities in the city of Bandar Lampung are very good. Electrical installations 
and Internet networks have reached every urban village. There is no area not covered by electricity and internet connection, so it is very easy to use the technology.

The results of identifying the economic strength of the population of Bandar Lampung city, most of the population of Bandar Lampung city is in the middle to upper economy, so it can be said that the population of the Bandar Lampung city is quite prosperous. Data from the National Economic Survey of the Indonesian Statistics Agency indicate that the poverty line, the number of poor educators and the percentage of poor in the city of Bandar Lampung are relatively low.

The socio-cultural condition of the city of Bandar Lampung is seen from the number of educational institutions, especially at the SMA / MA level in the city of Bandar Lampung, the results of the observation are quite numerous, namely 68 SMA which are under the Ministry of Education and Culture with details of 17 SMA with state status and 51 SMA with status private.

The results of the identification of the support of the government of the city of Bandar Lampung for improving the quality of educational resources include the existence of government institutions, such as the Ministry of Education and Culture, the Ministry of Religion, the Lampung Education Quality Assurance Agency.

Based on the results of the data collection, the results of the analysis of the external environment for the development of educational resources from Madrasah Aliyah in Bandar Lampung City include (1) the existence of a solid legal basis to improve the quality of educational resources (2) state of technology which supports (3) existence of secondary schools and Madrasah Aliyah in almost all sub-districts (4) most people are at a fairly prosperous economic level ( 5) there is a teachers' organization (6) there is government support through the ministry of education and culture, the ministry of religion and the LPMP.

The results of the research on planning strategies to improve the quality of educational resources for teachers at Madrasah Aliyah in Bandar Lampung City aim to identify the external environment. Identifying the external environment is relevant to the research findings of Muscalu, et al., Who found that the most important external factors that influence organizational activities are demographic, economic, and technical characteristics. and technology, socio-cultural, political, legislative, natural and international environment. The findings of this study are also relevant to the research findings of Muscalu, et al., Who found that the most important external factors that influence organizational activities are demographic, economic and technical characteristics. and technological, socio-cultural, political, legislative, natural and international environment [5]. Other studies have also shown that in general, the external environmental analysis will include macro-environmental and industrial environmental aspects. The macro-environment includes aspects related to political, legal, economic, social and technological aspects that can affect organizational activities. Meanwhile, the industrial environment is one that is closer to the organization's business activities [10].

Based on the conclusions and results of these relevant studies, to increase the effectiveness and competitiveness of madrasah teachers, decisions made by managers must take into account the links between the madrasah and the external environment. One of the most important characteristics of madrasas is their ability to adapt to changes that occur outside of the madrasa. This dependence can be evidenced by the most important external factors affecting the activities of the madrasah, especially in the planning of strategies to improve the quality of the resources of the teachers of the madrasah. The most important external factors affecting the working environment of an organization are the factors that determine the environment: demographic, economic, technical and technological, sociocultural, political, legal, natural and international. Organizations can function effectively if they are aware of external environmental factors as well as ongoing changes, continually adapting to the demands of the external environment. 


\section{Conclusion}

The external environment of Madrasah Aliyah in Bandar Lampung includes a clear legal basis; technological support; Economic situation; organization of teachers; colleges of teachers; and government support. The identification of the external environment of the madrasah should be broad by examining the various possibilities which could be both opportunities and threats to improve the quality of the resources of the teachers of the madrasah.

\section{References}

[1] Lynda Gratton, "The New Rules of Human Resource Strategy,” Fokus, pp. 13-14, 1998.

[2] K. Hengki Primayana, "Manajemen Sumber Daya Manusia Dalam Peningkatan Mutu Pendidikan Di Perguruan Tinggi," J. Penjaminan Mutu, vol. 1, no. 2, p. 7, 2016.

[3] N. Usman, Manajemen Peningkatan Mutu Kinerja Guru; Konsep, Teori dan Model. Bandung: Citapystaka Media Perintis, 2012.

[4] A. W. Tunggal, Manajemen Srategik untuk Memenangkan Kompetisi. Jakarta: Harvarindo, 2009.

[5] E. Muscalu, D. Iancu, and E.-E. Halmaghi, "the Influence of the external environment," J. Def. Resour. Manag., vol. 7, no. 2, pp. 133-138, 2016.

[6] A. R. Ommani, "Strengths, weaknesses, opportunities and threats (SWOT) analysis for farming system businesses management: Case of wheat farmers of Shadervan District, Shoushtar Township, Iran,” African J. Bus. Manag., vol. 5, no. 22, pp. 9448-9454, 2011.

[7] N. Fattah, Manajemen Strategik Berbasis Nilai. Bandung: Remaja Rosdakarya, 2015.

[8] Akdon, Strategic Management for Educational Management. Bandung: Alfabeta, 2011.

[9] Thomas L. Wheelen and J. David Hunger, Strategic Management and Business Policy Concepts and Cases, Eleventh E. USA: Prentice-Hall International USA, 2012.

[10] R. Ibrahim and I. Primiana, "Influence Business Environment On The Organization Performance,” Int. J. Sci. Technol. Res., vol. 4, no. 4, pp. 283-293, 2015.

[11] J. O.-G. and M. Simpson, "Achieving Competitive Advantage in The Mexican Footwear industry," an Int. J., vol. 14, no. 3, pp. 289-305, 2007. 